時效処理は常温加工処理のみの場合和よびひすみ時効 処理の場合に比較して, 疲労変形の防止に最も有効な 処理方法であるといいらる。しそがつて，これらのと とより,つる巻バネなどの疲労変形防止に有効なセッ チング応力の決定の指針になると考えられる。

\section{5. 結}

言

以上の実験結果叔よどその考察から次のととが明ら かとなつた。

（1）軟鋼材飞常温㨭り加工之同時に, 負荷のまま $300^{\circ} \mathrm{C}$ で 10 分間の低温焼䤠を施した応力時効好理を 行うときは, 常温加工妈理称よ゙荷重を零にもどした 状態に扣々て, 同じく $300^{\circ} \mathrm{C} て ゙ 10$ 分間の低温焼钝を 施したひすみ時効処理の場合に比較して, 片振り繰返 据り応力による疲学変形量をいちじるしく減少しう る.

（2）応力時効処理を施すときは, 常温加工和よび ひすみ時効の各処理の場合よりも疲労変形に及泫す七
ッチングの効果がさらに大きい.

（3）応力時効妈理を施すときは, 常温加工扣よび ひすみ時効の各処理の場合に比較して, 静降伏点, 破 断強さ, 扣よび硬度が相当上昇し, 破断までのひすみ 量が減少する。乙の結果はあらかじめ加える常温での 加工度が大きい长ど顕著である。

（4）乙れらの理由として，あらかじめ加える捩り 常温加工による加工硬化和よび残留応力の影響の上 に, 低温加熱による迄り碩化などの附加による合成結 果であると考えられる。

（5）な和, 今後の問題として, 最も効果的な応力 時効の処理条件, 平均応力の附加による影響, 痩労強 度に及敒す応力時効の効果, 応力時効の経年時効, 高 温疲労変形に及ぼす効果, 扣よび材料による時効効果 の相違などに関し研究を進める予定である。 注: -

1) 材料試䌞, 第 4 拳, 第24号, 375 頁

2）材料坛嗝, 第 3 巻, 第 15 号, 22 頁

\title{
鋼の疲労破壊の統計的研 究*
}

篠塚正宣**

\section{A Statistical Study on Fatigue Life of Steel}

\section{Masanobu SHINozuka}

It has been well known that the observed fatigue life for the constant repeated stress is scattered widely.

This experimental study was carried out in order to investigate the character of the frequency distribution of the fatigue life of steel.

The specimen was a flat bar with a circular hole in its center and not annealed. Its material was SS 41 steel.

The sort of repeated stress was the pulsating tension stress and the stress levels were $30 \mathrm{~kg} / \mathrm{mm}^{2}, 27 \mathrm{~kg} / \mathrm{mm}^{2}$, and $24 \mathrm{~kg} / \mathrm{mm}^{2}, 20$ specimens were tested each stress levelis with Lcsenhausen Fatigue Testing Machine (U.H.S. type). Besides these, to 20 specimens the stress level $24 \mathrm{~kg} / \mathrm{mm}^{2}$ was applied to failure after stress level $27 \mathrm{~kg} / \mathrm{mm}^{2}$ were applied 50000 cycles, in order to investigate the scatter of fatigue life of the specimen to which two different stress levels were applied.

Experimental errors were analized statistically.

The conclusion from experiment was as follows :

1. The scatter of fatigue life was well interpreted by introducing the probability of fracture $\mu$.

2. The method to estimate the probability of non-fracture was obtained.

3. The scatter observed in this experiment was considerably smaller than that reported by other investigators.

4. It was clarified that the scatter of fatigue life was not obtained from the experimental errcrs only. 


\section{1. 緒}

\section{㝘}

構造物を設計与る際に，最も大切なととは，使用す る材料の強度と加えられる荷重とを正しく推定すると とである。ととに，安全率の合理的な決定法が要望さ

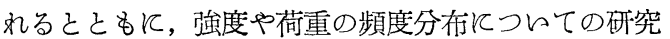
が，その基本的な間題としてとりあげられねね゙ならぬ ことがわかつてきた。本研究では, 疲労寿命の頻度分 有につ々て実験的研究を行ら, 試片の断面寸法, 表面 仕上げなぼを同一にし，同し試験機械を用ら，その操 作に十分な注意をしても，すなわち，外的条件をでを るでけ同一としても，かなり大きな疲労寿命のげらつ

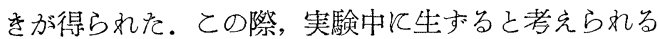
種々の誤差について検討し，ばらつきが実験誤差のみ から生じをものでないととを明らかにした。したがつ $\tau$, 上述の上う飞外的条件起同一としても, 疲労機構

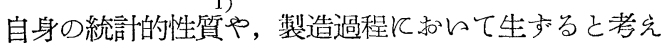
られる内的な，すなわち金属組織的な欠陷の差異のた めに, 疲労寿命が壮らつくものと考允られる。このよ

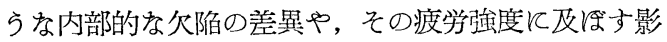
響を適格化理解するととは，な扣研究を要するととで あろう。乙かし，現在の段階として，個々の材料壮製 造過程に和いて異なつを程度の欠陷を生じながら, 全 く同し強度を持つものとして使用されているから, と れら材料の疲労寿命のばらつを謤価して叔くとと が, 安全度の点からいつて必要であると考允る。との ような観点から, 本研究では, 試片として実際の鋼橋 飞使用されているSS 41 の有孔平鋼板につロて疲労試 験を行つた。

\section{2. 疲労寿命の分布について}

疲労寿命がばらつくととについて, 近年二三の研究 がなされている．W.Weibull は鋼の迴転曲け゚疲労試 験を種々の一定繰返し応力で 9 本ずつ行い, そのばら つきから破壊の確率を計算する実験式を与えている。

A.M. Freudentahl は疲労寿命の分布が対数正規分 布をすると考爷た。その理由は次のようである。同一 繰返し応力を順次 $S_{1}, S_{2}, \cdots \cdots S_{k}$ とする。 乙れらは

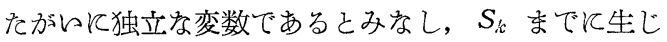
た破断断面積を $A_{k}$ とするとき

$$
\begin{aligned}
& A_{k}-A_{k-1}=S_{k} f\left(A_{k}\right) \quad \therefore \quad S_{k}=\frac{A_{k}-A_{k-1}}{f\left(A_{k}\right)} \\
& \text { したがつて } \\
& \sum_{k=1}^{N^{\prime}} S_{k}=\sum_{k=1}^{N^{\prime}} \frac{A_{k}-A_{k-1}}{f\left(A_{k}\right)}=\int_{A_{0}}^{A} \frac{d A}{f(A)} \\
& \quad=c \int_{A_{0}}^{A} \frac{d A}{A}=c \ln \frac{A}{A_{0}}
\end{aligned}
$$

そだし， $f(A)=A / c$ と仮定してある。ことに $A_{0}$


によれば， $\sum S_{k}$ は潮近的に正規分布に近づくことが わかつている。したがつて， $N^{\prime}$ 回までの断面積破壊
の程度の対数は正規分布をする。一方 $A / A_{0}$ は平均の 損傷の割合飞比例し，まを，乙の平均の損倠の割合は 疲労寿命 $N$ 飞大体反比例する。 したがつて $\ln (1 / N)$

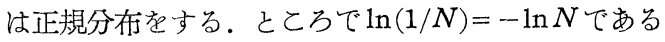
から， $\ln N$ も正規分布をする。 したがつて, 対数正 規確率紙を用的て破壊の確率の小さい $N$ を外捙䏓よつ て求めるのである。これが A.M. Freudentahl の方 法である。乙の方法では, 外插直線が実測值より非安 全侧の方へはな机る傾向にあるので好ましくない。

その後, A.M. Freudentahl 和上び E.J. Gumbel は，実際得られるデータは， $\log N$ が正規分布をす る母集団から抽出した十分大き的標本の最弱僆である とし，Nの分布はこの最妈值の分布であると考え，デ 一夕飞最小值の分布の理論を適用した。すなわち, $l(N)_{s}$ 㠻一定の繰返し応力和ける非破壊の確率とす ると,

$$
\begin{aligned}
l(N)_{s} & =\exp \left(-e^{\prime \prime}\right) \\
y & =\alpha^{\prime}{ }_{s}\left(x-u_{s}\right)
\end{aligned}
$$

そだし $\alpha^{\prime} s, u_{s}$ 注実験から求められる定数である。 ことに $x=\log N$ であり, $u_{s}=\log V_{s}, \alpha^{\prime}{ }_{s}=2 \cdot 3 \alpha_{s}$ と扣くと，

$$
l(N)_{s}=\exp \left(-\left(\frac{N}{V_{s}}\right)^{\alpha_{s}}\right)
$$

が得られる。乙の場合は確率紙として Gumbel 紙を用 レて, 破壊の確率が小さレ $N$ を外插によつて求めるの である.これが A.M. Freudentahl利よび E.J. Gumbel の方法である。．との方法をアルミニウムの回転曲げ度 労試験などの結果飞適用した例を見ると，Freudentahlの方法のような欠点はないが, 各繰返乙応力の外 插淔線が，破壊の確率の小さいととろで交わる場合を 生じ，乙のようなところでは，繰返し応力が小さい方 が破壊の確率が大きいと的矛盾を生ずるととな ๖.

横堀氏は以上の諸考察とは全く別反，物性論的立場 から, 大標本論的実験を根拠として, 疲労寿命がばら つくととは本質的なものであるととを主張している。 疲労破壊の過程は，(1)応力の加えはじめから加工硬 化の終りまで，(2)加工硬化の終りから損倠の発生ま で, ( 3 )損傷の発生から割れ目の発生(破壊)までの 3 段階が考兊られる。氏快実験の結果，(1)の段階の繰 返し回数は他の段階に比べて十分小さらとと，和よび (2)，(3)の段階は確率過程と考光られるととを明ら かにした。 しかし，(2)の段階も(3)反比べて十分短 からので, $N_{c}$ 回の繰返し以後の割れ目の発生が確率 過程の問題であるとして，

$\mu(N)$ : 任意の繰返し数 $N$ K扣々て割れ目が毎サイ クル当り発生する確率(ただし $N$ は $N_{\iota}$ から 計算する) 
$q(N) d N$ : 繰返し回数 $N$ の後で, $N$ と $N+d N$ サイ

クルとの間で割れ目の発生する確率

$p_{l}(N)=\int_{N}^{\infty} q(N) d N$ : 澡返し回数 $N$ 以後で割れ目

の発生する確率

とすると， $q d N=p_{l} \mu d N$ であるから

$$
\mu=-\frac{d\left(\ln p_{l}\right)}{d N}
$$

したがつて, $\ln p l$ と $N$ との間の関係をプロットし， その勾配からルを求めるととがで きる。加はヒストグラムを有に 当か, $p_{l}=1-i /(1+n)$ 加求め る。後者の $p_{l}$ は $n$ 個の試片のう ち, 小さいものから $i$ 番目の大き さの $N$ 《対与る超過の確率を与充 る。実験は $870^{\circ} \mathrm{C} て ゙ 30$ 分間焼杘 しした $0.41 \%$ の炭素䤱の回転曲 げと $0.19 \%$ の炭素鋼の引張り圧 縮度労飞つ的て行われ, その結果, ほ凬隹一定であるととが認めら

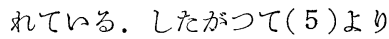

$$
p_{l}=\exp (-\mu N)
$$

である。当的ついて物理的な意味

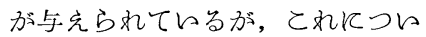
ては交献(1)を参照されたい。

さて，上述の研究につ々て考察 すると，A.M. Freudentahl 和上 び E.J. Gumbel の考光方は, 疲 労寿俞の分布が大きな正のひする
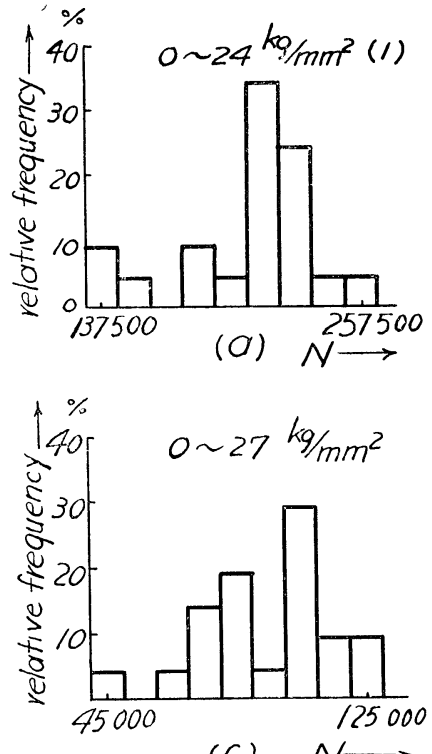

(C)



Fig. 1. Specimen,
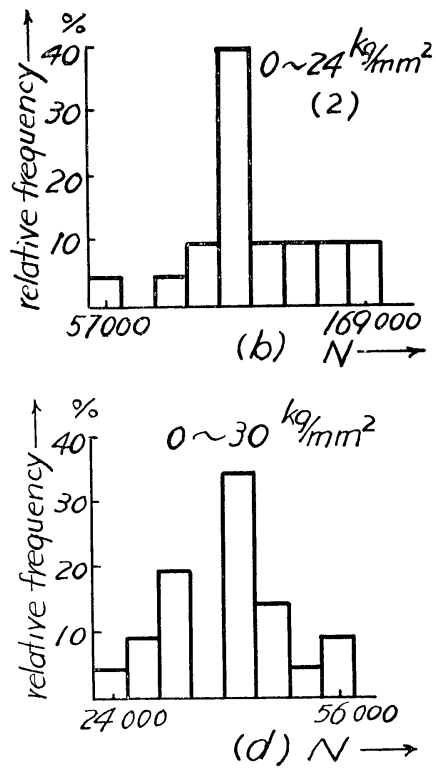

Fig. 2. Frequency distribution of fatigue life.

度をもつととを説明するのを主眼としていると考允ら れる。横堀氏の考方方も，疲労破壊の現象が電気火花 やガラスの割れ目の間題と類似しているとと，すなわ ち, その疲労寿命が繰返乙回数の十分小さいところか ら分布し，かつ，その分布が大をな正のひずみ度をも つといら実験結果を物性論的な考え方加ら説明してい るわけである。とてろが次節で結果が示されているよ うに，鉒者が行つを実験では，疲労寿命の分布は䡩著 な正のひずみを見出すととができなかつた。したがつ て, 筆者の実験結果飞詨しては, 疲労寿命の分布が詨 数正規分布であると考えるととは囦難である。また， 後述するように(5)式の ない、笔者の試片は焼杘しがされて和らず, 圧延のまま であり,焼居しした場合と大分条件が変つてくる.さら 飞前述のように，実際の構造用鋼なぞて生じている内 部的欠陷の差買のための疫労寿命のげらつをを無視す るわけにはいかないと考元られる。したがつて,少なく とも普通の品質管理状態で製造されを部材の疲労寿俞 のばらつをは，疲労寿命を確率過程と考えた場合のば らつをと，欠陮の差異和よび実験誤差によるげらつき

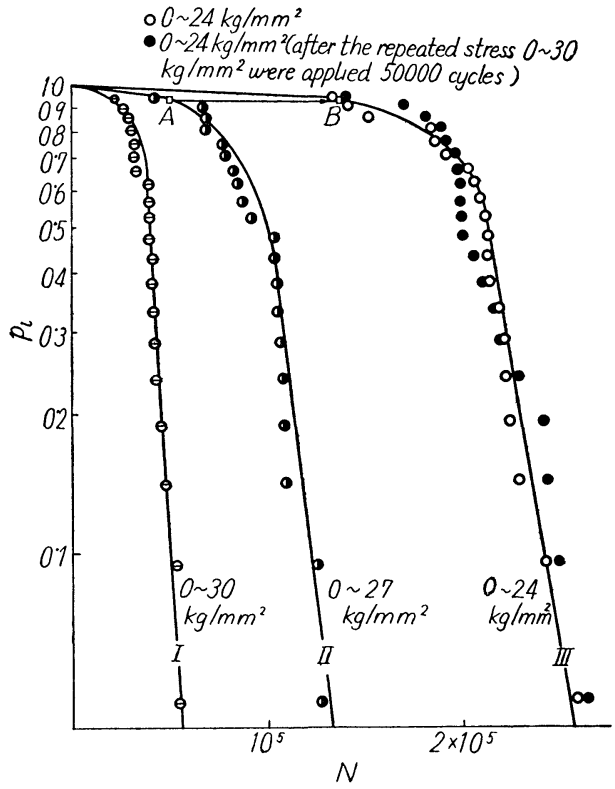

Fig. 3. The relation between $p_{l}$ and $N$ 
とが含まれて的ると考光られる。しかし，実験結果の

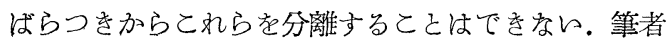
の実験では, 疲学寿命の分有の確率法則䞟明確飞とら えるととは, 試験片の数からいつても困難である。し かし， $\mu$ の物理的な意味を追及しなければ，上述の の定義をとのまま用的，疲労現象を一種の確率過程 と考劣ると便利である。

\section{3. 実験むよびその考察}

試片寸法は Fig. 1 のようである。表面は圧延のまま とし, 侧面は shaping machine とより切削した。孔明 けは drilling machine によつて行われた。試験は Losenhausen fatigue testing machine (U.H.S. 型) そよつて行われ，毎分 800 茴の繰返し速度で片振引張 り応力を与えた。繰返し応力は (1) $0 \sim 30 \mathrm{~kg} / \mathrm{mm}^{2}$, (2) $0 \sim 27 \mathrm{~kg} / \mathrm{mm}^{2}$, ( 3 ) $0 \sim 24 \mathrm{~kg} / \mathrm{mm}^{2}$ の 3 種類, 和よび (4) 最初 $0 \sim 27 \mathrm{~kg} / \mathrm{mm}^{2}$ が 50000 回繰返され た後, 破断するまで $0 \sim 24 \mathrm{~kg} / \mathrm{mm}^{2}$ が繰返される場合 である。和の和のについて試片数は20本とした。実験 結果は Table 1 亿示される. 疲労寿命の分布はヒスト

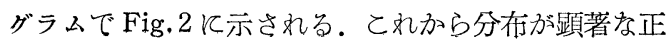

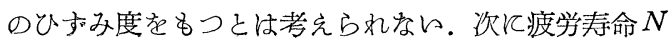
と非破壊の確率 $p_{l}$ との関係は Fig. 3 亿示される。 I, II, III の曲線は, それぞれ $0 \sim 30 \mathrm{~kg} / \mathrm{mm}^{2}, 0 \sim 27$ $\mathrm{kg} / \mathrm{mm}^{2}$, 和よび 0 2 $24 \mathrm{kgmm}^{2}$ の繰返し応力に対応

Table 1. Fatigue life from experiment

\begin{tabular}{|c|c|c|c|c|c|}
\hline $\begin{array}{c}\text { number } \\
i\end{array}$ & $p l=1-\frac{i}{1+n}$ & $\begin{array}{c}N \\
\left(0 \sim 24 \mathrm{~kg} / \mathrm{mm}^{2}\right)\end{array}$ & $\begin{array}{c}N \\
\left(0 \sim 27 \mathrm{~kg} / \mathrm{mm}^{2}\right)\end{array}$ & $\begin{array}{c}N \\
\left(0 \sim 30 \mathrm{~kg} / \mathrm{mm}^{2}\right)\end{array}$ & $\begin{array}{c}N * \\
\left(0 \sim 24 \mathrm{~kg} / \mathrm{mm}^{2}\right)\end{array}$ \\
\hline 1 & 0.952 & 136180 & 44000 & 24040 & 5120 \\
\hline 2 & 0.905 & 143780 & 68730 & 28160 & 35050 \\
\hline 3 & 0.857 & 155030 & 70690 & 29801 & 46770 \\
\hline 4 & 0810 & 187790 & 70770 & 32280 & 54400 \\
\hline 5 & 0762 & 188540 & 78590 & 33030 & 56400 \\
\hline 6 & 0.714 & 195720 & 80750 & 33540 & 59590 \\
\hline 7 & 0.667 & 203640 & 84.340 & 34.630 & 61120 \\
\hline 8 & 0.619 & 208840 & 86460 & 40960 & $621 \subseteq 0$ \\
\hline 9 & 0.571 & 211090 & 89250 & 41090 & 62190 \\
\hline 10 & 0524 & $2143 \subseteq 0$ & 94.840 & 41380 & 63480 \\
\hline 11 & 0.476 & 215210 & 105740 & 41 ๖70 & 63950 \\
\hline 12 & 0.423 & 215410 & $10 \overline{9} 920$ & 42010 & 69880 \\
\hline 13 & 0.381 & 215570 & 106030 & 42900 & 75190 \\
\hline 14 & 0.333 & 221700 & 107730 & 43330 & 82050 \\
\hline 15 & 0.286 & $2232 \subseteq 0$ & 103120 & 444.50 & 85460 \\
\hline 16 & 0238 & 223580 & 109470 & 44. $6 \subseteq 0$ & 93210 \\
\hline 17 & $0 \cdot 190$ & 225120 & 110310 & 46460 & 105330 \\
\hline 18 & 0.143 & 230420 & 111420 & 48600 & 107810 \\
\hline 19 & 0035 & 243180 & 126540 & 53550 & 112490 \\
\hline $20=n$ & 0018 & 259180 & 128010 & 54100 & 124440 \\
\hline
\end{tabular}

* after the repeated stress $0 \sim 27 \mathrm{~kg} / \mathrm{mm}^{2}$ were applied 50000 cycles.
する。曲線がすべて $p_{l}=1, N=0$ の点から出発して ロるのは大をな仮定である。すねわち, 各試片は繰返 し応力が加光始められるとすぐに，前節で定義したよ うK，各 1 回の繰返しごとに破壊の確率をもつわけで あつて,その大きさは,との曲線の公配比例するわけ である.（4)式に和いてもとの仮定が尔されている。 まを, 横堀氏の方法化和いては $N_{c}$ が十分小さいとい

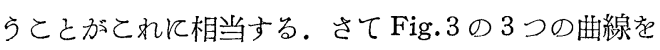

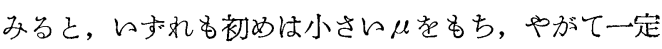
飞近づくことがわかる。すし $0 \sim 27 \mathrm{~kg} / \mathrm{mm}^{2}$ の繰返し 応力を試片に与えると, この試片は繰返し回数が増す とともに, 曲線I沿つて非破堎の確率が减ずるとと となるわけで，その試片の疲労寿命を明言するととは できないが, 指定さ礼る繰返し回数まで到達できる確 率を推定するととはできる。このように一定の繰返し 応力のみが加えられる場合ならば，曲線 I, II, III な ぞがわかつていれば，てれに沿つて非破壊の確率を推 定するととがでをる。一般の変動応力が作用して試片 が破断する場合には，間題は複雑である。最も簡単な 場合として，2段の繰返し応力を考穴て実験( 4 )起行 つそ。試片はまお曲線Iに沿つてA点まで澾する。A 点は $0 \sim 27 \mathrm{~kg} / \mathrm{mm}^{2}$ の繰返し応力が 50000 回繰返さ れたときの非破壞の確率を与える。A点と同じ非破壊 の確率の点 Bを曲線III上飞求めると，0〜24 kg $/ \mathrm{mm}^{2}$ の繰返しはB点を出発点として 曲線III 亿沿つて,非破壊の確率 が推定されるとととなる。した がつて, 0 24 kg/ $\mathrm{mm}^{2}$ の繰返 乙回数は B点から数完られると と飞なる。乙の考壳から，実験 (4)の結果をもFig. 3 とプロッ トしてある。この結果は曲線III にかなりよく一致する。したが つて,とのような 2 段の繰返し 応力の場合飞は, 一定応力の繰 返しの場合の曲線を 2 本用的 ば, その非破壊の確率を推定す るととができる。

さて，実際の部材の設計に際 しては， $p_{l}$ として大き的值を採 用しなければならない. Fig. 3 でわかるようと别が大きいと ころでは， $\mu$ は小く一定であ り, $\log p_{1}$ と $N$ とは直線関係 酒ある仮定してある。したが つて, との部分では ( 5 )式から 加を求めるととがでをる。さら そ，2段の繰返し応力の場合で 
も，2つの曲線とよつてとの非破壊の確率が推定でき るのであるから，乙の場合も $p_{l}$ が大きく $N-p_{l}$ 線 が直線と考光られるととろでは，(5)式から繰返し応 力 $0 \sim S_{1}$ K和ける $N_{1}$ 回の繰返しによる $p_{11}$ 和よび $0 \sim S_{2}$ K和ける $N_{2}$ Kよる $p_{l 2}$ を求めると，乙の $N_{1}+N_{2}$ 回炕よる非破壊の確率 $p_{l}$ は $p_{l}=p_{l 1} \cdot p_{l 2}$ と して求められる。複雑な変動応力の場合飞も, とのよ らな考方方を拡張するととができるであるう。最後に 注目すべきは, 本実験に利ける疲労寿命のばらつきは，

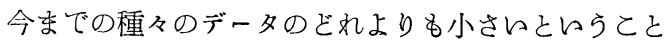
である、との点酒関しては, 筆者の用いた試片は, 外 の実験に用いられを試片に比べて，(1)応力集中があ るとと, (2)表面仕上げや孔明けが粗なとと, (3)焼 戻しがされて和らず, 圧延のままなとと，などが大き な原因と考完られる。

な和, 本実験では各繰返し応力ととに20本の試片を 用的が，乙の程度の本数では分布の母集団を推定与 るには不足であると思われる（もち万ん，適当な母集 団を仮定するととは容易であるが，それ対する信頼 性はうすい)。乙たがつて，とこでは母集団を追及する ととをせ方, 破壊の確率 $\mu$ 在用的て, 疲労寿命 $N$ と


壊の確率を考慮した $S$ - $N$ 線図を Fig. 4 亿示す。

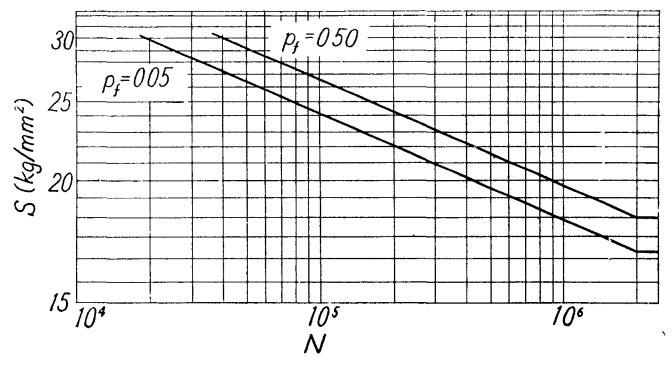

Fig. 4. $S-N$ diagram.

\section{4. 実 験 誤 差}

Table 1 の結果には種々の実験誤差が含まれてい る. その和もなものは，(1)試片断面の測定和よび推 定の誤美，(2)荷重指示目盛の感度和よび精度に関す る誤差, (3) 実験中の油压の変動飞よる誤差, (4) 真 の動的油圧と指示目盛との差による䛊差, である。と れらを分析し，疲労寿命のばらつきがこのよらな誤差 から得られるととが否定できなければ，そのばらつを

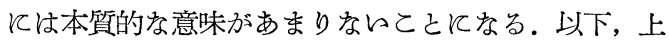
$の(1) \sim(3)$ の誤差について考察する. (4)について は, 試験機械の動的桧定が行われていないので論するる ととが困難であるが，たと充，乙の点保差があつて も, 公称応力が上下与るだけで, 疲学寿命の分有注 影響がないと考兊る。

（1）は測定器具の感度叔よび精度に関するものと，
孔の雨侧の最小断面積の幅 $g$, 厚さ $t$ の推定の際飞生 するるのとがある. 長さの測定や推定関する誤差を 正規分有と仮定し, 実測值甲加工公差加ら $g, t$ の分 布の標準偏差を求めると, $\sigma_{g} \fallingdotseq 0.1 \mathrm{~mm}, \sigma_{t} \doteqdot 0.05 \mathrm{~mm}$ となる。 2 つ断面積は大体等しいから，その和は近 似的飞 $N\left(\bar{A}, \sigma_{A^{2}}{ }^{2}\right)$ 飞をがう。ととに, $\bar{A}=2 \bar{g} \cdot \bar{t}$, $\sigma_{A}{ }^{2}=2\left(\bar{g}^{2} \sigma_{t}+\bar{t}^{2} \sigma_{g}{ }^{2}\right)$, そぞし $\bar{A}, \bar{g}$, 和よび $\bar{t}$ は,そ れぞれ $A, g$, 和よび $t$ の真の值である。

さて, 試片飞最大公称平均応力度 $S_{n}$ を与光るには,

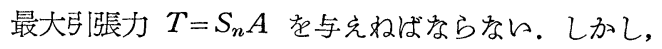
$A$ は前述のようと真の断面積 $\bar{A}$ とは異なつている。 ゆえに, この試片に生じている実際の最大平均応力度 $S_{a}$ は

$$
S_{a}=-\frac{T}{\bar{A}}=\frac{S_{n} A}{\bar{A}}
$$

したがつて，一陚片の $S_{a}$ の分布は $A$ が正規分布を するととから， $N\left(S_{n}, \sigma_{s}^{2}\right)$ 飞したがう。をだし，

$$
\sigma_{s}=\frac{S_{n}}{\bar{A}} \sigma_{A}=\frac{S_{n}}{\bar{A}} \sqrt{2\left(\vec{g}^{2} \sigma_{t}^{2}+\vec{t}^{2} \sigma_{g}^{2}\right)}
$$

もし全試片の $\bar{A}$ が同一なら，すべての試片を考慮し そときの $S_{a}$ の分有も前と同し分布飞従う。乙かし，

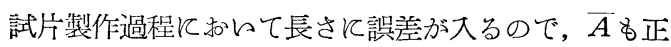

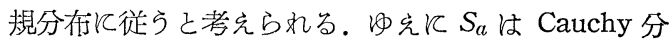
布に従うが, $\bar{A}$ の試片による差は大きくはなく，厳密


代りに,

$$
\sigma_{s a}=\frac{S_{m}}{A_{\mathrm{mi} 2}} \sigma_{A}
$$

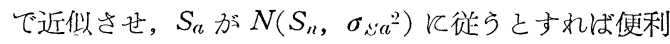
でもあるし，安全侧でもある。 $\bar{g}, \bar{t}$ として公称寸法を 用らると $\sigma_{A}=1.96 \mathrm{~mm}^{2}$ となり， $A_{\min }$ として垁測值 の最小 $410 \mathrm{~mm}^{2}$ 在用的，(8)より $S_{n}=30,27$ ，和上 び $24 \mathrm{~kg} / \mathrm{mm}^{2}$ そつけて $\sigma_{\mathrm{s} a}$ 在計算すると，それぞれ $0 \cdot 143,0 \cdot 129$, 打よび $0 \cdot 115 \mathrm{~mm}^{2}$ である。

(2)については, 筆者の用いそ機栈では, 最大引張 力の指示板が $200 \mathrm{~kg}$ どとに目盛られているから, そ の最大誤差は大体 $\pm 100 \mathrm{~kg}$ としてよい. とれによる 平均応力度の誤差の最大值は大体 $\pm 100 / 400= \pm 0 \cdot 25$ $\mathrm{kg} / \mathrm{mm}^{2}$ である。荷重指示の誤差も正規分布と考光， 実際の荷重がこの範囲から外れるととはほとんどない と的う条件(外机当確率を1\%とした)から，標潐偏差 $\sigma_{m}$ 注約 $0.1 \mathrm{~kg} / \mathrm{mm}^{2}$ である。

(3)はその取り扱いがむずかしい，油圧したがつて 最大和よび最小荷重は, この種の機械の性質として, 種々の原因により実験中飞変動し, 最大荷重叔よび最 小荷重の指示板上の針のふれとして認められる。しか 乙, 最大荷重がある指定荷重 $T_{l}$ 以下に下つた場合, 油圧がプラスされて下限が $T$ に 亿保をれ，まを，最大 荷重がある值 $T_{u}$ 以上飞なると, 機俄の運転が停止さ 
れるような上限荷重 $T_{u}$ を指定でをるようになつてい る。最小荷重に対しても同じようなコントロール方法 がとられている。すなわち，最大和よび最小荷重はそ れぞれの上限と下限との間を変動する。.以下では取り

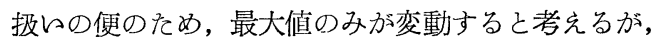
このようにしても安全侧である。この変動する最大荷 重の疲労に及に゙す効果が，同じ繰返し回数の変動しな 的ある最大荷重で代表されるものと仮定すると，機械 の性質中運転の経験かららつて，との代表荷重の分布 は $T_{l}$ を下限とする指数分布と見なすととができる。 乙たがつて, 最大平均応力度 $S_{a}$ の分布は $T_{l}$ 亿対する $S_{l}$ を下限とする指数分布 $k \exp \left\{-k\left(S_{a}-S_{l}\right)\right\}$ 飞従う ことになる。数 $k$ は $S_{a}$ が $T_{u}$ 亿效する $S_{u}$ を超える ととがないという条件(非超過の確率を $99 \%$ とした)持 よど $T_{u}-T_{l} \doteqdot 200 \mathrm{~kg}$ ，すなわち $S_{u}-S_{l}=0.5 \mathrm{~kg} / \mathrm{mm}^{2}$ を用的て計算すると，9.22 となる。

上述のように，3つの誤差は正規分布と指数分布の 2 つの型にわけられる. 実験結果として表われるの は，乙れらの累計である。正規分布の再生性により， (1), (2) の誤差の分布の合成は $S_{n}=30,27$, 执よび

Table 2. Expected numbers from theoretical distribution of experimental errors.

(1) $S_{n}=30 \mathrm{~kg} / \mathrm{mm}^{2} \quad k=9.22 \quad \sigma_{\ell}=0.173$

\begin{tabular}{c|c|c|c|c|c|c|c|c|c|c}
\hline$S_{a} \mathrm{~kg} / \mathrm{mm}^{2}$ & 28.0 & 28.5 & 29.0 & 295 & 30.0 & 30.5 & 31.0 & 31.5 & 32.0 \\
\hline$F\left(S_{a}\right)$ & & & & 0.00084 & 0.30500 & 0.56551 & & & \\
\hline$N$ & 69000 & 60000 & 52000 & 47000 & 40000 & & 30000 & & 23000 \\
\hline obtained & 0 & & 2 & 1 & 10 & 4 & 3 & 0 \\
\hline expected & & 0 & & 6.2 & 13.8 & & 0 \\
\hline
\end{tabular}

(2) $S_{n}=27 \mathrm{~kg} / \mathrm{mm}^{2} \quad k=9 \cdot 22 \quad \sigma_{x}=0 \cdot 161$

\begin{tabular}{c|c|c|c|c|c|c|c|c|c}
\hline$S a \quad \mathrm{~kg} / \mathrm{mm}^{2}$ & $25 \cdot 0$ & $25 \cdot 5$ & $26 \cdot 0$ & $26 \cdot 5$ & $27 \cdot 0$ & $27 \cdot 5$ & $28 \cdot 0$ & $28 \cdot 5$ & $23 \cdot 0$ \\
\hline$F(S a)$ & & & & $0 \cdot 00015$ & $0 \cdot 29450$ & $0 \cdot 97050$ & & & \\
\hline$N$ & 159000 & 141000 & 119000 & 100000 & 50000 & 80000 & 69000 & 60000 & 52000 \\
\hline obtained & 0 & 2 & 8 & 1 & 4 & 3 & 1 & 0 & 1 \\
\hline expected & & 0 & & & $5 \cdot 9$ & $14 \cdot 1$ & & & 0 \\
\hline
\end{tabular}

(3) $S_{n}=24 \mathrm{~kg} / \mathrm{mm}^{2} \quad k=9 \cdot 22 \quad \epsilon_{2}=0.150$

\begin{tabular}{c|c|c|c|c|c|c|c|c|c|c|c}
\hline$S_{a} \mathrm{~kg} / \mathrm{mm}^{2}$ & $22 \cdot 0$ & $22 \cdot 5$ & $23 \cdot 0$ & $23 \cdot 5$ & $24 \cdot 0$ & $24 \cdot 5$ & $25 \cdot 0$ & $25 \cdot 5$ & 260 \\
\hline$F(S a)$ & & & & 0.00005 & $0 \cdot 28800$ & $0 \cdot 97397$ & & & \\
\hline$N$ & 440000 & 380000 & 310000 & 270000 & 220000 & 190000 & 159000 & 141000 & 119000 \\
\hline obtaıned & & 0 & 7 & 8 & 2 & 2 & 1 & 0 \\
\hline expected & & 0 & $5 \cdot 8$ & $14 \cdot 2$ & & 0 & \\
\hline
\end{tabular}

$24 \mathrm{~kg} / \mathrm{mm}^{2}$ 飞対して，S $S_{a}$ はをれどれ $N\left(30 ， 0 \cdot 173^{2}\right) ，$ $N\left(27,0 \cdot 161^{2}\right)$, 和上び $N\left(24,0 \cdot 150^{2}\right)$ 飞彷う. 次 亿指数分布と正規分布との合成を考元る。

簡単のため, $x$ が $N\left(\bar{x}, \sigma_{z^{2}}{ }^{2}\right)$ 飞, $y$ が密度函数 $k \exp (-k y)$ 飞従う変数とすると, $z=x+y$ の確率 エレメントは,

$$
\begin{aligned}
& f(z) d z \\
& \quad=\left(\int_{-\infty}^{z} k e^{-k(z-x)} \frac{1}{\sqrt{ } 2 \pi \sigma_{x}} e^{--\frac{(x-\bar{x})^{2}}{2 \sigma_{x}^{2}}} d x\right) d z
\end{aligned}
$$

となる。とれより分布函数を求めると，

$$
\begin{aligned}
& F\left(S_{a}\right)=\int_{-\infty}^{S a} f(z) d z=\emptyset\left(S_{a}\right) \\
& -e^{\frac{k}{2}\left\{k \sigma_{x}^{2}-2\left(S_{a}-\bar{x}\right)\right\}} \Psi\left(S_{a}\right) \\
& \Phi\left(S_{a}\right)=\int_{-\infty}^{S a} \frac{1}{\sqrt{2 \pi} \sigma_{x}} e^{-\frac{(z-\bar{x})^{2}}{2 \sigma_{x}^{2}}} d z, \\
& \Psi\left(S_{a}\right)=\int_{-\infty}^{S a} \frac{1}{\sqrt{2} \pi \sigma_{x}} e^{-\frac{\left\{x-\left(\bar{x}+k \sigma_{x}^{2}\right)\right\}^{2}}{2 \sigma_{x}^{2}}} d x
\end{aligned}
$$

である。したがつて，F( $\left.S_{a}\right)$ を計算より求めるととが でをる。（9)在用いて，各 $S_{n}$ ごとに平均応力度の分布を計算 し，それ《よる疲労寿命 $N$ の ばらつをの期待個数を求め, 実 測個数と比較したのが Table 2 である。この結果，Nのばらつ

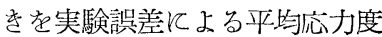
のばらつきのみから説明すると とは囦難侯と考完る。 そだし，表中の $N$ の值は， $S$ 之 $N$ とが一義的飞定まり，それが Fig. 4 の $p_{f}=0.5$ の直線で表 わされるものとして求めてあ る。

\section{5. 結 需}

以上のととを総合すれね゙，次 のよう㷧る。

（1） $S-N$ 線図は破坡の確 率を考慮して描かれね济ならな b.

（2）破填の確率 ると，Nのばらつきを説明する の飞便利である。 $\mu$ 梳 $N-\log p_{2}$ 図から求めるととがでをる。 SS 41 の圧延のままの有孔平鋼 板では, $\mu$ は初めは小さく, 後 飞一定嗦る。

（3）一定繰返し応力をうけ

「材料試験」第 4 卷第 25 号 
る同じ材料については, $N-\log p_{l}$ 図が求められていれ ば，その非破壊の確率が推定できる，2段の繰返し応 力につ々ても, 対応する 2 本の $N-\log p_{l}$ 図加ら, 非 破壞の確率を求めるととができる。

（4）本実験に扣ける疲労寿命のばらつをは，外の 実験結果に比べて小さい.

（5）本研究では, 実験䛊差について十分検討を加 え, 得られた疲労寿命のばらつきが, 実験誤差のみか ら生じたものではないととを明らかにした。

本研究は筆者が京都大学大学院工学研究科修士課程
に扣々て行つた研究の概要である. 本研究の遂行に際 し, 終始, 御懇切な御指導を賜つた京都大学教授小西 博士にたいし，深謝の意を表わします。

注 : 一

1) T. Yokobori, J. Phys. Soc. Japan, 8, 265 (1953)

2) W. Werbull, Fatigue and Fracture of Metals, p. 182 (1952)

3) A.M. Freudentahl, Am. Soc. Test. Mat., STP, No. 121 (1952)

4) A.M. Freudentahl and E. J. Gumbel, Proc Roy. Soc, London, A, 216, 309 (1953)

5) 平田森三, 応用統計学, 11.01 (1951)

\section{高周波焼入と疲れ強度*}

$$
\text { 中村宏 }{ }^{* *} \text { 高橋秀 雄*** }
$$

\section{Induction Hardening and Fatigue Strength.}

\section{Hiroshi Nakamura and Hideo Takahashi}

In order to explain the effect of induction hardening on fatigue strength, we tried several fatigue tests by changing. the stress concentration factor $\alpha_{K}$.

We used $\mathrm{C}=0.41 \%$ steel, and chose the three types, as the heat treatments.

The following facts were cleared up from the experimental results.

(i) At normalized specimens, $\alpha_{K}$ becomes greater than $\beta_{K}$, as we have known already.

(ii) At ordinary quenching (heating in electric furnace and quenching in water), $\alpha_{K}$ equals approximately $\beta_{\boldsymbol{K}}$.

(iii) At induction hardening, the fatigue limits is considerably high, and does not change largely by changing of $\alpha_{\kappa}$.

It was apparent that, within the range of the investigation, the greater $\alpha_{K}$ the larger became the effect of induction hardening on the fatigue limit.

Lastly we discussed the reason why the fatigue limits became high by induction hardening.

\section{1. 緒言}

著者の一人は，先飞高周波焼入は圧入部や切火部の 疫れ限度をいちじるしく上昇せしめらるという事実を 見出した。そして切欠部分の疲労腨度増加の原因とし て次の 2 つが考えられる.

1. 表面核残留する圧縮応力

2. 急速加熱により, 材質的にも通常の電気炉㮱入 したものより鞀性を有する。

これら 2 つ原因について，より詳しく検討するた め, 今回は形状係数 $\alpha_{K}$ を種々変えて実験し, 乙の場 合湻周波焼入がどのような作用をするかというとと を検討した。

\footnotetext{
* 原稿受村 昭和 30 年 4 月 26 日

** 正員 鉄道技術研究所

$* * *$ 高周波熱鍊株式会社
}

昭和 30 年 9 月
これまで著者の一人が高周波焼大の実験に用いた馬 欠試験片は, 直径 $d=10 \sim 12 \mathrm{~mm}$ の試験片に対して切 欠底半径 $\rho=0.25 \mathrm{~mm}$ のものであつた。そして, 今ま でのデータをみると，高埖焼入の疲れ限度に対する 影響は， $\alpha_{K}$ の大なる試料ほど顕著にでており，平滑

Table 1. Comparison of various fatigue limits.

\begin{tabular}{c|c|c|c}
\hline \multirow{2}{*}{ No. } & Heat treatment & \multicolumn{2}{|c}{ Fatigue limits $\mathrm{kg} / \mathrm{mm}^{2}$} \\
\cline { 2 - 3 } & $\begin{array}{c}\text { Plain } \\
\text { specimen }\end{array}$ & $\begin{array}{c}\text { Notched } \\
\text { specimen } \\
\alpha_{K=3}\end{array}$ \\
\hline 1 & Induction hardening & 66 & 56 \\
\hline 2 & Ordinary hardening & 49 & 11.5 \\
\hline & $1 / 2$ & 1.34 & 4.86 \\
\hline
\end{tabular}

